\title{
Boros Anita
}

\section{A megfelelöség ellenörzésének egyes kérdései \\ az állami tulajdonú gazdasági társaságok esetében}

\begin{abstract}
ÖsszeFoGLALó: Az állami tulajdonú gazdasági társaságok sajátos helyet foglalnak el az állami (köz)feladatellátás rendszerében. Meg kell felelniük a jogszabályi előirásoknak, az adott gazdasági társasággal szemben már az alapitáskor megfogalmazott célkitǔzéseknek, a tulajdonosi, esetenként kormányzati szinten megfogalmazott elöirásoknak, a szakpolitikai (ágazati) szintǔ szabályozóknak, szabványoknak, a közszolgáltatást igénybe vevők által támasztott elvárásoknak, a szervezet által magával szemben lefektetett rövid, közép- és hosszú távú stratégiai céljainak, a vezetőkkel és a munkavállalókkal szemben megfogalmazott vállalati értékeknek. Tanulmányunk arra keresi a választ, hogy van-e erre valamiféle útmutatás az állami tulajdonú gazdasági társaságok számára, illetve miként lehet egyáltalán ellenőrizni az állami tulajdonú gazdasági társaságok megfelelőségét. A kutatásaink eredményeként megállapítottuk, hogy a hazai szabályozás csak részlegesen foglalkozik a megfelelőség kérdéskörével és egységes normatív szabályozási hiátus tapasztalható az állami tulajdonú gazdasági társaságok vonatkozásában. Az államigazgatási szervekre, valamint a biztositási és hitelintézeti sztérára irányadó szabályozás áttekintése alapján megfogalmaztuk azokat a szabályozási tárgyköröket, amelyeket megfontolásra javasolunk az állami tulajdonú gazdasági társaságok megfelelőségi ellenőrzési alapjainak megteremtéséhez.
\end{abstract}

KuLcsszavak: állami tulajdonban lévő gazdasági társaság, belső kontrollrendszer, compliance, integritás, megfelelőségi ellenőrzés JEL-Kód: G38, K20, M14, H83, M48

DOI: https://doi.org/10.35551/PSZ_2019_4_6

Az állami tulajdonú gazdasági társaságok sajátos entitások az állami feladatellátás rendszerében: közpénzből működnek, főként közfeladatot látnak el, tevékenységük legtöbbször nagyon költséges és általában közvetlenül nem profitábilisak. Az állam új típusú ellenőrzési politikájának hatóköréből azonban nem kerülhet-

Levelezési e-cím: boros.anita@uni-nke.hu nek ki az állami tulajdonú gazdasági társaságok sem, sőt rájuk még szigorúbb szabályok vonatkoznak. Hipotézisünk, hogy az állami tulajdonú gazdasági társaságok esetében a szűkebb értelemben vett közpénzügyi és tulajdonosi ellenőrzésen kívül a megfelelöségi ellenőrzés tágabb értelemben vett fogalomrendszerébe tartozó kontrollfunkciókat is ki kell építeni.

Tanulmányunk elsőként bemutatja, hogyan alakult az állami ellenőrzési mechanizmusok 
köre az állami tulajdonban lévő gazdasági társaságok vonatkozásában 2010 óta. Ezt követően megvizsgáljuk, hogy a megfelelőségi ellenőrzésnek milyen hazai előzményei vannak és azok eredményei miként implementálhatók a jelenlegi állami vállalati rendszerbe. Végezetül saját szempontrendszer alapján szabályozási javaslatok bemutatására kerül sor, rámutatva, hogy újra kell értelmezni az állami tulajdonú gazdasági társaságok fölötti széttöredezett kontrollmechanizmusok szinergikus jegyeit.

\section{AZ ÁLLAMI TULAJDONÚ GAZDASÁGI TÁRSASÁGOK JELLEMZÓI - ALAPVETÉS}

A hazai állami tulajdonú gazdasági társaságok rendszere igen heterogén képet mutat. Szemben a magánszféra akvizícióival, az állam csak nagyon ritkán alapít üzleti megfontolásból gazdasági társaságot vagy vásárol befektetési célból, illetve nyereségszerzés reményében társasági részesedést. Az ilyen társaságok létrehozására inkább akkor kerül sor, amikor egy állam által ellátandó feladat hatékonyabban megvalósítható egy általa tulajdonolt gazdasági társaság útján, mint egy költségvetési szerv keretein belül. Ezeknél a társaságalapításoknál legföképpen a közjó érdekében szükséges intézkedések, így például a különböző nemzetstratégiai, ellátásbiztonsági vagy folyamatos közüzemi biztosítási, nemzetgazdasági szinten megjelenő biztonságpolitikai szempontok játszanak szerepet. Ebből következően elenyésző azoknak az állami tulajdonú gazdasági társaságoknak a száma, amelyek for-profit jellegüek és jelentős az úgynevezett alvó társaságok köre is, amelyek ténylegesen nem végeznek tevékenységet, de az állami tulajdonú gazdasági társaságok körébe kerültek, jellemzően öröklés útján. Ezek az alvó társaságok többnyire kényszertörlés, végelszámolás és felszámolás alatt állnak. Ezek hányada a Magyar Nemzeti Vagyonkezelő Zrt. (a továbbiakban: MNV Zrt.) portfóliójába tartozó társaságok körét tekintve igen jelentős, több mint negyven százalék (lásd 1. táblázat). ${ }^{1}$

A felesleges, vagyis a közfeladat ellátásához már nem szükséges társasági részesedéseket az MNV Zrt. fó szabály szerint elektronikus árverés útján próbálja értékesíteni. Az MNV Zrt. honlapjának tanúsága szerint a 2018 nyarán meghirdetett közel 80 társaság részesedésének felét sikerült csak az első licit alkalmával értékesíteni. ${ }^{2} \mathrm{Az}$ értékesítést megnehezíti a társaságok heterogén jellege, ${ }^{3}$ társasági működtetésre alkalmas volta, értéke, hiszen nem egyszer már évek óta nem működő társaságokról van szó. Érdemes arra is utalnunk, hogy ezek az adatok nem a teljes állami cégportfóliót mutatják, hiszen a működő gazdasági társaságok (társasági részesedések) számát növelik az olyan társaságok is, amelyek tekintetében a tulajdonosi jogokat nem az MNV Zrt. gyakorolja (közvetetten ${ }^{4}$ sem). Ez akként lehetséges, hogy például a szakpolitikai felügyeletet gyakorlóhoz került a tulajdonosi joggyakorlás is. Örök dilemma az ilyen társaságok tekintetében, hogy vajon az egységes szakmai és tulajdonosi joggyakorlás vagy éppen azok szétválasztása a hatékonyabb megoldás. A hazai gyakorlatban 2010 után inkább az egységes tulajdonosi joggyakorlás volt jellemző (vagyis néhány kivételtől eltekintve az állami vagyon felügyeletéért felelős miniszter és az MNV Zrt. gyakorolta a tulajdonosi jogokat). A szakmapolitikai érdekek és elvárások ezt a modellt néhány év múlva kezdték feloldani és egyre gyakoribbá vált, hogy az említetteken kívül más(ok) - jobbára a szakmai felügyeletet gyakorló szerv - lett a tulajdonosi joggyakorló is. 2018 után az említett első modellt felváltotta egy széttöredezettebb tulajdonosi-joggyakorlói szerkezeti modell. Nyilván mind a két szélsőséges megoldásnak vannak előnyei és hátrányai, azonban témánk szempontjából egy aspektus feltétlenül kiemelendő: a kisszámú tulajdonosi joggyakorló esetén lényegesen egyszerűbb az egységes vállalat- 


\section{AZ MNV ZRT. PORTFÓLIÓJÁBA TARTOZÓ TÁRSASÁGOK ÖSSZETÉTELÉNEK ÖSSZESÍTETT ADATAI}

\begin{tabular}{l|c|c}
\hline \multicolumn{1}{|c|}{ Társasági részesedések } & $\begin{array}{c}\text { Társasági részesedés } \\
\text { mértéke (db) }\end{array}$ & $\begin{array}{c}\text { Társasági részesedés } \\
\text { mértéke (\%) }\end{array}$ \\
\hline MNV Zrt. porttoliójába tartozó társaságok & 303 & 100,00 \\
\hline $\begin{array}{l}\text { ebból az MNV Zrt. által közvetlenül kezelt társaságok } \\
\text { ebból megbizásba, vagyonkezelésre átadott társaságok }\end{array}$ & 296 & 97,69 \\
\hline $\begin{array}{l}\text { MNV Zrt. által közvetlenül kezelt társaságok közül többségi } \\
\text { állami tulajdonú társaságok (50\%+1 szavazattal) összesen }\end{array}$ & 7 & 2,31 \\
\hline $\begin{array}{l}\text { MNV Zrt. által közvetlenül kezelt társaságok közül } \\
\text { kisebbségi állami tulajdonban lévők }\end{array}$ & 154 & 52,03 \\
\hline $\begin{array}{l}\text { MNV Zrt. által közvetlenül kezelt társasági } \\
\text { részesedésekből múködó társaságok }\end{array}$ & 172 & 47,97 \\
\hline $\begin{array}{l}\text { MNV Zrt. által közvetlenül kezelt társaságok közül a nem } \\
\text { múködő társaságok }\end{array}$ & 120 & 59,46 \\
\hline
\end{tabular}

Forrás: www.mnv.hu (2019. 06. 12.)

irányítás elveinek a kimunkálása és tulajdonosi ellenőrzése, míg a sok tulajdonosi joggyakorló esetében, azok egységes mederbe terelése és a tulajdonosi aktusok egységesítése a számos aktor részvétele okán nehézkes, ezáltal eltérőségek jelentkezhetnek a különböző tulajdonosi joggyakorlóhoz telepített társaságok esetében. Ez nem csak működési eltérőségeket, hanem már eleve feltételrendszerbeli, tervezési, stratégiai különbözőségeket is eredményez. Témánk szempontjából ez azért bír jelentőséggel, mert a megfelelőség egyik kulcskérdése, hogy milyen feltételrendszernek, céloknak, elvárásoknak, szabályoknak kell megfelelnie egy állami tulajdonban lévő gazdasági társaságnak, és ezek tényleges ellenőrzése milyen állami kontrollmechanizmusokat feltételez?

Az állami tulajdonban lévő gazdasági társaságok elsődleges rendeltetése az állami közfeladat-ellátás támogatása. Éppen ezért minden társaság vagy társaságcsoport más-más irányítási metodikát kíván az általa ellátott (köz) feladathoz igazodóan. Összehasonlíthatatlan például egy évtizedek óta veszteséget termelő nagy közszolgáltató társaság(csoport), és a piacon egyedüli, monopolhelyzetben lévő, valójában az állami feladatellátás „kényelmesebb” szegmensébe tartozó társaság irányítása. Az azonban kétségtelen, hogy „csakis a jól, hatékonyan és eredményesen irányitott állami (...) tulajdonú gazdasági társaságok szolgálják a köz érdekét. Az általuk kezelt vagyon a köz tulajdona, tevékenységük és gazdálkodásuk minösége, eredményessége és hatékonysága egyfelöl hozzájárul a felelös közpénzgazdálkodáshoz, másfelöl az általuk elóállitott javak és szolgáltatások számos esetben érintik a lakosság életminöségét, biztonságát, egészségét és jólétét." - fogalmaz a Domokos László és szerzőtársai által jegyzett tanulmány (Domokos, Várpalotai, Jakovác et al., 2016). Ebből egyúttal az is következik, hogy az államnak meg kell találnia azokat az eszközöket, amelyekkel elősegítheti, hogy az állami tulajdonú gazdasági társaságok valóban hatékonyan és eredményesen gazdálkodjanak a rájuk bízott közvagyonnal. 
Az ilyen társaságok a feladat jellege mellett olyan értelemben is sajátos helyzetben vannak, hogy a rájuk bízott közvagyonból kell biztosítaniuk valamilyen - többnyire költséges - állami feladat ellátását. A nyereség valójában az esetükben a közszolgáltatás színvonalának növekedésében és az állampolgárok elégedettségében mérhető. Mivel ezeknek a közjavaknak a finanszírozása az eredeti jövedelmek megadóztatásából kerül finanszírozásra (Zéman, 2017), kiemelt figyelmet kell fordítani nemzetgazdasági szinten is az állami vállalatok (köz)feladat ellátásához kapcsolódó egyes részterületeinek megfelelő mélységű ellenőrzésére.

\section{AZ ÁLLAM ELLENŐRZÉȘI SZEREPKÖRE AZ ÁLLAMI TULAJDONÚ GAZDASÁGI TÁRSASÁGOK ESETÉBEN}

Az állami tulajdonú gazdasági társaságok meghatározzák egy adott állam gazdálkodását, ${ }^{5}$ szakpolitikai szabályozási metodikáját. Az állam saját vállalataihoz való viszonyát az $\mathrm{OECD}$ is vizsgálta és ajánlásaiban ${ }^{6}$ felhívta a figyelmet annak kiemelt jelentőségére, hogy az adott állami vállalatot, milyen közpolitikai célból alapították. $^{7} \mathrm{Az}$ OECD ennek a tényét tekinti kiinduló pontnak és kiemelte, hogy ki kell alakítani a megfelelő tulajdonosi irányítási mechanizmusokat, amelyek e célok megvalósítását leginkább szolgálják anélkül, hogy az állami vállalatok vezetőinek felelősségét az irányításba történő beavatkozással korlátozná. Az OECD által vizsgált tagállamok esetében kimutatott fokozódó állami ellenőrzés és a tulajdonosi eszközrendszer felértékelődése 2010 után hazánkban is tapasztalható volt (Boros, 2017).

A magyar nemzetgazdaság a kétezres évek elejétől elmélyülő problémákkal küzdött: az államháztartás adósságai, az alacsony hatékonyságú költségvetési politika és a gyenge ellenőrzési potenciál tovább mélyült a 2007-2008-as válság idején (Lentner, 2018; Lentner, 2019).
Ahogyan Lentner Csaba közismert tanulmányában (Lentner, 2015b) is kifejtette, a 2007 ben kirobbant válság óta lényeges változások álltak be az állampénzügyek területén. „Új idöket élünk, amely új megoldásokat követel, és ez különösen igaz a közpénzek területén. Azért kellett váltani, azért kellett új szabályokat lefektetni és új intézményeket létrehozni, mert a korábbi évek krónikus állami túlköltekezését és az államadósság drasztikus megemelkedését sem az Allami Számvevöszék, sem pedig az egyéb független intézmények nem tudták megakadályozni." - olvasható az Állami Számvevőszék elnökének egy 2011-es tanulmányában (Domokos, 2011). A változás számos területen megmutatkozott (Lentner, 2015b), így

- különösen intézményi szinten például a jegybanki és az első sarkalatos törvényként elfogadott (Domokos, 2016) számvevőszéki (Domokos, Pulay, Pető et. al, 2015) szabályozásban,

- az állami működésbe vetett bizalom erősödésének támogatásában,

- a hatékony adórendszer kialakításában (Lentner, 2015b),

- az adósságplafon alkotmányos szintre emelésében (Domokos, 2011),

- a hatásos és hasznos ellenőrzési rendszer kimunkálásában, illetve nem utolsósorban a Költségvetési Tanács Alaptörvényben történő megerősítésében (Kovács, 2016; Kovács, 2014; Domokos, 2011).

Az aktív állami szerepvállaláson alapuló magyar modellben a nemzetgazdasági szinten érvényesülő ellenőrzési rendszer célja olyan irányba változott, amely elősegítette az arra jogosult valós beavatkozását a pénzügyi folyamatokba. Ahogyan Lentner Csaba fogalmaz "alapveto" nemzeti érdek, hogy átlátható, hatékony és számon kérhetö legyen a magyar közpénzekkel és a nemzeti vagyonnal való gazdálkodás. Szakszerü és rendszeres ellenörzés nélkül nem képzelhetö el Magyarország felemelkedése, a jelenlegi gazdasági és társadalmi problémák le- 
küzdése." (Lentner, 2015b) Ezek a változások odavezettek, hogy az államnak a saját vagyonába tartozó gazdasági társaságai irányába is új típusú ellenőrzési elvárásokat kellett megfogalmaznia. Ezek az elvárások egyfelől szabályozási szinten (külső tényezők), másfelől pedig a vállalatirányítás és a belső kontrollmechanizmusok (belső tényezők) szintjén is egyre erőteljesebben jelentkeznek.

A külső tényezők tekintetében a szabályozási oldalt röviden megvizsgálva megállapíthatjuk, hogy a közpénzzel való megfelelő gazdálkodás az Alaptörvényből levezethető kötelezettség (Domokos, Várpalotai, Javovác et.al., 2016). Az alkotmányos szabályokat egészítik ki a vagyonnal kapcsolatos törvények. Egyfelől a nemzeti vagyonról szóló 2011. évi CXCVI. törvény (a továbbiakban: Nvtv.), az állami vagyonról szóló 2007. évi CVI. törvény (a továbbiakban: $V t v$.) és annak végrehajtási rendelete. Az általános vagyonjogi szabályozók mellett kiemelt szerepet játszanak a vállalati működés általános szabályait meghatározó polgári jogi rendelkezések, illetve a köztulajdonban álló gazdasági társaságok takarékosabb működéséről szóló 2009. évi CXXII. törvény sajátos, állami vállalatokra vonatkozó szabályai is.

Szintén egy meghatározó jogforrási kört képeznek a közpénzügyi normatív szabályokat lefektető jogforrások is, különös tekintettel az államháztartásról, a számvitelről, az adózás rendjéről és az egyes adónemekről, valamint illetékekről szóló törvények és azok végrehajtási rendeletei, a közbeszerzési és versenyjogi szabályozás, valamint a különböző szektorspecifikus szabályozók is, amelyek további követelményeket állapítanak meg az egyes közszolgáltatásokat nyújtó gazdasági társaságok tekintetében (Lentner, 2015a).

Emellett természetesen számos egyéb gyakran nemzetközi implementációs kötelezettségből fakadó - normatív és annak nem minősülő szabályozó határozza meg az állami vállalatok működésének kereteit (különösen a közszolgáltatási ágazatokban).

A gazdasági társaságok egyedi, sajátos müködési rendeltetését, célját azonban nem az említett szabályozókban találjuk. A hazai gyakorlatban új, állami tulajdonú gazdasági társaság alapítása esetén ugyanis többnyire kormányhatározat rendelkezik a gazdasági társaság létrehozásának céljairól, az alapításhoz szükséges főbb ismérvek meghatározása mellett. A kormányhatározatokban előírtakat aztán a tulajdonosi joggyakorló fogalmazza meg az állami vállalatok irányába, társasági jogi értelemben joghatás kiváltására alkalmas aktusban, vagyis tulajdonosi döntésben. ${ }^{8}$ Ebből következően relevánsak a tulajdonosi határozatok is. Az ilyen tulajdonosi határozatokat aztán minden egyes társaság leképezi a saját döntéshozó fórumainak aktusai útján is. Ezek azonban már a társaságon belül keletkező, általunk csak a belső tényezők kategóriájába sorolt jognyilatkozatként értékelhetők. Nem szabad megfeledkeznünk az állami tulajdonú gazdasági társaságok sokrétű, olykor kazuisztikus belső szabályrendszeréről sem, amelyek szintén befolyásolhatják egy ilyen típusú gazdasági társaságok rugalmas vagy éppen merev müködési metodikáját. Végezetül ebbe a körbe soroljuk a vezető tisztviselö, illetve a különböző jogállású társasági szervek aktusait is, amelyek szintén nagymértékben hozzájárulhatnak a modern állami vállalati müködési feltételrendszer kialakításához.

Valójában az állami vállalatok működésének célrendszerét determináló minden előírás és követelmény érvényesülése egy-egy olyan kérdéskör, amelynek hiátusai alapot adhatnak arra, hogy az adott társaság létjogosultsága megkérdőjelezhetővé váljon. A neoliberális gazdasági rendszerben gyökeret eresztő (Polanyai, 2001) és az állam passzivitására építő, menedzser jellegü állammüködéssel szemben az elmúlt időszakban teret nyerő, a keynesi filozófia újraéledéseként is felfogható, az aktív állami szerepvállalásra támaszkodó gazdálko- 
dási rendszer „a jó állammüködés alapját jelentik"(Lentner, 2019). Az állam megfelelő szintű aktivitása (Lentner, 2019) tehát elengedhetetlen. A kérdés, hogy miként tudja az állam ellenőrizni az állami vállalatok müködésének megfelelőségét, helyénvalóságát?

\section{A MEGFELELŐSÉG ELLENŐRZÉSE AZ ÁLLAMI VÁLLALATOK ESETÉBEN}

A megfelelőség a magánszférában már elterjedt és a gyakorlatban is kimunkált területnek tekinthető. A nagyobb magántulajdonú cégeknél külön compliance terület foglalkozik a vállalati megfelelőség kérdésével. A megfelelőség kérdésköre azonban nem csak a vállalati szféra sajátja, hiszen számos tudományterület foglalkozik azzal, hogy miként lehet betartatni az adott szférára vonatkozó előírásokat (Cramer, Roy, Burrell et al., 2008; Simon, Clinton, 2009). A megfelelőség egy igen összetett fogalom, hiszen magában foglalja többek között a pénzügyi, a gazdasági, az adózási, az üzleti, a jogi, az etikai, a fenntarthatósági, a tulajdonosi megfelelőséget is.

A megfelelőségi ellenőrzések során az Állami Számvevőszék azt vizsgálja, hogy az ellenőrzés tárgyát képező „tevékenység vagy müködés minden lényeges szempontból megfelel-e az ellenörzött szervezetre vonatkozó szabályozásoknak és követelményeknek" (A megfelelőségi ellenőrzés alapelvei, 2015). Itt érdemes utalnunk arra is, hogy az Állami Számvevőszék a megfelelőségi ellenőrzés két altípusát különbözteti meg: a szabályszerűségi, illetve a helyénvalósági ellenőrzést. Az ellenőrzési eljárások során sor kerülhet a két módszer kombinálására is. A szabályszerűségi ellenőrzés elsődlegesen a jogi szabályozóknak való megfelelés vizsgálatára irányul, míg a helyénvalósági ellenőrzés épp az olyan területekre terjed ki, amelyeknél valamilyen normatív szabályozási hiátus érzékelhető, és az alapelvek a megfelelőségi ellenőrzés azon altípusa, amelyet azokban az esetekben kell alkalmazni, amelyekre jogszabályi előírások nem alkalmazhatók, illetve amennyiben egyes kérdések megítélésénél nyilvánvaló jogszabályi hiányosságok tapasztalhatók, és az adott kérdés az alapelvek vagy az elfogadott gyakorlatok alapján ítélhető meg.

Egy szervezet megfelelőségének vizsgálatakor valójában arra keressük a választ, hogy annak működési mechanizmusai alárendelhetők-e a szervezetre vonatkozó valamenynyi elöírásnak, a vele szemben megfogalmazott célkitűzéseknek és elvárásoknak. Szűkebb értelemben a megfelelőség egy gazdasági társaságra vonatkozó jogi szabályozók - ide értve a tulajdonos döntéseit is - betartását és betartatását jelenti. Tágabb értelemben azonban sokkal többet jelent: az adott gazdasági társasággal szemben már az alapításkor megfogalmazott célkitűzéseknek, a tulajdonosi, esetenként kormányzati szinten megfogalmazott előírásoknak, a szakpolitikai (ágazati) szintű szabályozóknak, szabványoknak, a közszolgáltatást igénybe vevők által támasztott elvárásoknak, a szervezet által magával szemben lefektetett rövid, közép- és hosszú távú stratégiai céljainak, a vezetőkkel és a munkavállalókkal szemben megfogalmazott vállalati értékeknek való megfelelést is jelenti.

Olyan konkrét szabályozó jelenleg nincs, amely a köztulajdonban álló gazdasági társaságok számára adna iránymutatást a megfelelőség belső szabályozását tekintve, noha ennek a kérdéskörnek a vizsgálata nemzetközi szinten is egyre elterjedtebb.

A megfelelőség kérdésköre és az ehhez kapcsolódó kontrollfunkció kimunkálása hazánkban jogszabályi szinten főként a hitelintézeti és a biztosítási jog területén jelent meg az elmúlt években (Kovács, Szóka, 2016). Ezekben az ágazatokban a jogszabályi megfelelőség szabályrendszere került igen magas szinten, törvényekben kimunkálásra. Természetesen az állami tulajdonú gazdasági társaságok számára is 
léteznek fogódzkodók, azonban a terminológiai eltérőségek okán gyakorta nem is tudatosul a társaságokban az, hogy egy-egy megfelelőségi kérdéskörrel találkoznak.

Az államháztartásról szóló 2011. évi CXCV. törvény (a továbbiakban: Áht.) értelmében az államháztartási kontrollok célja az államháztartás pénzeszközeivel és a nemzeti vagyonnal történő szabályszerü, gazdaságos, hatékony és eredményes gazdálkodás, a beszámolási és adatszolgáltatási kötelezettségek szabályszerü teljesítésének biztosítása. ${ }^{9}$

Az Nvtv. 10. $\$(2)$ bekezdése szerint a tulajdonosi joggyakorló rendszeresen ellenőrzi a nemzeti vagyon használójának a nemzeti vagyonnal való gazdálkodását, megállapításairól értesíti a nemzeti vagyon használóját, továbbá, amennyiben megállapításai az Állami Számvevőszék hatáskörét érintik, az Állami Számvevőszéket is. Az állami vagyon feletti tulajdonosi joggyakorlással kapcsolatos tevékenységet az Állami Számvevőszék évente ellenőrzi. ${ }^{10}$ Emellett az MNV Zrt. rendszeresen ellenőrzi a vele szerződéses jogviszonyban lévő személyek, szervezetek vagy más használók állami vagyonnal való gazdálkodását, megállapításairól az MNV Zrt. felügyelőbizottságát, az ellenőrzött szervet, szükség esetén a minisztert és az Állami Számvevőszéket tájékoztatja. ${ }^{11}$

Az Áht. az államháztartási kontrolloknak különböző szintjeit nevesíti, így szól

• a külső - az Állami Számvevőszék, valamint az Áht. által meghatározott esetekben a kincstár -,

- a kormányzati - a kormányzati ellenőrzési szerv, az európai támogatásokat auditáló szerv, illetve a kincstár -,

- valamint a belső ellenőrzési funkciókról a hatálya alá tartozók vonatkozásában (Domokos, Várpalotai, Javovác et.al., 2016).

A közszférára vonatkozó INTOSAI belső kontrollstandardok alapján megállapítható, hogy „a belsö kontroll egy dinamikus, összetett folyamat, amely folyamatosan alkalmazkodik a szervezetet érö változásokhoz. A vezetésnek és a dolgozók minden szintjének részt kell vennie ebben a folyamatban, hogy a kockázatokat meghatározzák, és ésszerü biztositékot nyújtsanak a szervezet küldetésének teljesitéséhez, és kitüzött céljai eléréséhez." "12 A COSO-modellben a belső kontroll egy olyan folyamat, amelyet a társaság igazgatósága, a menedzsment és az alkalmazottai befolyásolnak, amelyet azért hoznak létre, hogy ésszerű bizonyosságot nyújtsanak olyan szervezeti célok elérését illetően, mint a hatékony és eredményes működés, a belső és külső pénzügyi beszámolás megbízhatósága, és a vonatkozó jogszabályoknak, előírásoknak, a belső szabályzatoknak való megfelelés.

Az államháztartási kontrollok és az állami tulajdonú gazdasági társaságok közötti kapcsolatot - az említett vagyonjogi szabályok mellett - lényegében az Áht. 69/A. \$-a teremti meg, amely szerint a kormányzati szektorba sorolt egyéb szervezetek belső kontrollrendszerére a költségvetési szervek belső kontrollrendszerére vonatkozó szabályokat alkalmazni kell. ${ }^{13} \mathrm{~A}$ kormányzati szektorba sorolt egyéb szervezetekről jelenleg egy PM-közlemény rendelkezik (HÉ 2018/36.). Az Áht. 1. \$ 12. pontja nevesíti a kormányzati szektorba sorolt egyéb szervezet fogalmát. Ebbe a körbe tartoznak azok a szervezetek, amelyek az Áht. alapján nem részei az államháztartásnak, azonban az Európai Közösséget létrehozó szerződéshez csatolt, a túlzott hiány esetén követendő eljárásról szóló jegyzőkönyv alkalmazásáról szóló, 2009. május 25-i 479/2009/EK tanácsi rendelet szerint a kormányzati szektorba tartoznak. A kormányzati szektorba sorolt egyéb szervezetet több kötelezettség terheli, mivel a központi költségvetésről szóló törvény elkészítéséhez köteles adatszolgáltatást teljesíteni az államháztartásért felelös miniszternek, a központi költségvetés végrehajtásáról szóló törvényben kötelezően bemutatandó összeállítások elkészítéséhez adatszolgáltatást kell teljesíteni, az ál- 
lamháztartásról szóló törvény végrehajtásáról szóló 368/2011. (XII. 31.) Korm. rendeletben (a továbbiakban: Ávr.) meghatározott rendszeres adatszolgáltatásokra köteles, és a Magyarország gazdasági stabilitásáról szóló 2011. évi CXCIV. törvény 9. \$-a alapján adósságot keletkeztető ügyletet csak az államháztartásért felelős miniszter elözetes egyetértésével köthet érvényesen, az adósságot keletkeztető ügyletekhez történő hozzájárulás részletes szabályairól szóló 353/2011. (XII. 30.) Korm. rendeletben foglaltak szerint.

A hivatkozott közlemény I. részében ${ }^{14}$ a közlemény kiadásakor működő, így az ismertetett előírásokat törvény alapján teljes körűen érvényesíteni köteles kormányzati szektorba sorolt egyéb szervezetek találhatók. A közlemény A) pontja rendelkezik a Központi kormányzat alszektorba besorolt szervezetekről. ${ }^{15}$ Az itt felsorolt száznegyvenhét szervezet többsége valamilyen állami tulajdonban lévő gazdasági társaság. ${ }^{16}$

A belső ellenőrzésre vonatkozó szabályokról az Áht. 47. alfejezete rendelkezik, míg a belső kontrollrendszer részletszabályait a költségvetési szervek belső kontrollrendszeréről és belső ellenőrzéséről szóló 370/2011. (XII. 31.) Korm. rendelet (a továbbiakban: Bkr.) határozza meg, amelynek hatálya kiterjed a kormányzati szektorba sorolt egyéb szervezetekre is. ${ }^{17}$

A Bkr. ugyanakkor nem szól a megfelelőség kérdésköréről, hanem a belső kontrollrendszer elemeire vonatkozó egyes szabályokat határozza meg.

Valójában tehát az látható, hogy az állami tulajdonú gazdasági társaságok megfelelőségére, integritására, belső ellenőrzésére nincsen sajátos, kifejezetten erre a körre kimunkált jogi szabályozó, hanem különböző utaló szabályokkal az államháztartási jog költségvetési szervekre vonatkozó egyes szabályait kell alkalmazni. Elgondolkodtató, hogy vajon nem lenne-e célszerü egy önálló jogszabályban meghatározni az általunk vázolt sajátosságokra figyelemmel az állami tulajdonú gazdasági társaságok külső ellenőrzésének és belső kontrollmechanizmusainak védelmi vonalaira vonatkozó szabályokat? A válaszunk egyértelműen az, hogy hiánypótló lenne egy ilyen zászlóshajó jogszabály kimunkálása, hiszen az állami tulajdonban álló gazdasági társaságok ellenőrzése nagyon öszszetett folyamat. Azok működését részben a vagyonjog és a (köz)pénzügyi jog, részben a polgári jog, illetőleg részben a - fóként szakigazgatási - közigazgatási jog határozza meg. Ebből következően az ellenőrzési mechanizmusok is ilyen ellenőrzési fókuszterületekre koncentrálódnak, és gyakran nem érvényesül közöttük az ellenőrzési szinergia. A tulajdonosi ellenőrzésnek például minden egyes részterületre ki kellene terjednie, de a pénzügyi vagy jogi megfelelőség vizsgálatán túl arra mindenképpen, hogy vajon az adott szervezet a tulajdonos - vagyis az állam - és az annak szolgáltatásait igénybe vevők - az állampolgárok és szervezetek - elvárásainak, igényeinek, a létrehozáskori céloknak megfelel-e. Az állami tulajdonú gazdasági társaságok működésének teljes spektrumát felölelő ellenőrzések egyik nehézsége az ilyen társaságok fölötti irányítás és a tulajdonosi jogkör gyakorlás megosztása több szervezet között. Így például lehetséges, hogy a tulajdonosi joggyakorló és a szakmai felügyeletet ellátó teljesen elkülönül egymástól, amely számos nehézséget okoz a mủködtetésben, a finanszírozásban és nem utolsósorban az ellenőrzésben is. Emellett a tulajdonosi joggyakorlók közötti szinergia megteremtése is gyakran nehézkes: a különböző jogalapok mentén létrejövő tulajdonosi joggyakorlások azt eredményezik, hogy azok tartalmi sajátosságai is lényegesen eltérnek egymástól. Csak egy példát említve: kiemeltük, hogy mennyire fontos az üzleti tervezés és az ezzel kapcsolatos tulajdonosi iránymutatás. Ennek vonatkozásában az üzleti tervek felépítése, tartalma, 
főbb elemei kapcsán egyes tulajdonosi joggyakorlók tervezési irányelveket munkálnak ki, míg mások az adott társaság támogatásán túl, annak müködtetésében egyáltalán nem vesznek részt.

Az kétségtelen, hogy sokrétü a normáknak az a köre, amelyeknek egy állami tulajdonú gazdasági társaságnak meg kell felelnie. A jogszabályokban nevesített ellenőrzési funkciók természetesen az intézkedések színes tárházával rendelkeznek, azonban a számtalan felügyeleti, ellenőrzési, tulajdonosi jogosítvány az ellenőrzési jogosítványok széttöredezését is eredményezi egyúttal és maradnak olyan szegmensek, amelyeket az adott gazdasági társaságnak belülről kell ellenőrizni. Ehhez egy hatékony belső kontrollrendszer kialakítása szükséges. A belső kontrollrendszer egy folyamatrendszer, amely tartalmazza mindazokat az elveket, eljárásokat és belső szabályzatokat, amelyeket a költségvetési szervnek azért kell kialakítania és müködtetnie, hogy valamennyi tevékenysége szabályszerü legyen, összhangban a gazdaságosság, hatékonyság és eredményesség követelményeivel (Kovács, 2007; idézi: Gyüre, 2012; Kis, 2015). Úgy véljük, hogy ennek a kereteit jogszabályi szinten kell meghatározni.

A megfelelőség és az integritás terminológiai elhatárolása tekintetében érdemes utal- nunk az alábbiakra: az Állami Számvevőszék által, az államigazgatási szervek korrupciómegelőzési helyzetének felméréséhez, korrupcióellenes kontrolljai kiépítéséhez és érvényesítésük ellenőrzéséhez kimunkált Módszertani útmutató ${ }^{18}$ szerint a latin eredetű integritás érintetlenséget, romlatlanságot, sértetlenséget jelent. Eszerint az integritás szervezeti értelemben egy adott szervezet társadalmi elvárásoknak megfelelö, szilárd értékrendnek alárendelheto” működését jelenti. Az Állami Számvevőszék által 2011-ben indított Integritás felmérés célja „az etikus, transzparens müködést károsan befolyásoló kockázatok azonositása, illetve az ezek kezelésére szolgáló kontrollok feltérképezése" (Németh, Bartus, Szabó, 2016). Röviden ez azt jelenti, hogy „azt teszi, amire létrehozták, úgy teszi, ahogy elvárják töle, és beteljesiti a küldetését" (Pulay, Jenei, 2016). Ebből is látható, hogy a szervezeti integritás és a megfelelőség egymáshoz közeli fogalmak és talán egy elhatárolási lehetőség lehet az, ha összevetjük az általunk kifejtett megfelelőségi definíciót az integritás kapcsán írtakkal. Kétségtelen, hogy a két fogalomrendszerben megjelenő célok azonos vertikumon helyezkednek el. Minél magasabb szintű egy szervezet integritása, annál hatékonyabbak a megfelelőségi kontrollok is (lásd 2. táblázat).

2. táblázat

\section{A 2016-2018. ÉVI INTEGRITÁSI FELMÉRÉSBEN RÉSZTVEVŐK INTEGRITÁSI VESZÉLYYZTETETTSÉGÉT ÉS A KONTROLLOK KIÉPÍTETTSÉGÉT TÜKRÖZÖ EVT-, VNT- ÉS KET INDEXEI}

\begin{tabular}{|c|c|c|c|}
\hline Index & $\begin{array}{l}\text { Az index értéke } \\
\text { 2016-ban } \\
\text { (\%) }\end{array}$ & $\begin{array}{c}\text { Az index értéke } \\
\text { 2017-ben } \\
(\%)\end{array}$ & $\begin{array}{c}\text { Az index értéke } \\
\text { 2018-ban } \\
\text { (\%) }\end{array}$ \\
\hline Eredendő Veszélyeztetettségi Tényezők (EVT) & 48,4 & 41,4 & 41,6 \\
\hline Veszélyeztetettséget Növelő Tényezók (VNT) & 35,2 & 25,0 & 27,8 \\
\hline Kontrollt Erősítő Tényezők (KET) & 60,0 & 49,8 & 46,6 \\
\hline
\end{tabular}

Forrás: saját összeállítás az Állami Számvevőszék 2016-2018. évi integritási felmérései alapján 
A SZERVEZETI INTEGRITÁS

ÉS A MÉGFELELÓSÉG TÁMOGATÁSÁNAKK
LEHETÓSEEGEI AZ ÁLLAMI TULAJDONÚ
GAZDASÁGI TÁRSASÁGOKNÁL -
KONKLUUZIÓ ÉS JAVASLATOK

Ahogyan azt említettük, az állami tulajdonú gazdasági társaságok müködése, az őket érinto” társadalmi bizalmi faktor meghatározó az állam működése, nemzetközi vagy éppen társadalmi megítélése, versenyképessége, hatékonysága szempontjából. Ennek okán úgy véljük, nagyon fontos annak vizsgálata, hogy milyen feltételrendszernek, céloknak, elvárásoknak, szabályoknak kell megfelelnie egy állami tulajdonban lévő gazdasági társaságnak, és ezekhez milyen állami kontrollmechanizmusokat érdemes telepíteni? Az bizonyos, hogy ezeknek a társaságoknak a müködését fokozottan, ténylegesen kell ellenőrizni: mind törvényességi, mind vagyongazdálkodási, mind tulajdonosi, mind közpénzügyi szempontból. Az ellenőrzési mechanizmusoknak ki kell terjednie számos, egy-egy ellenőrzési területhez csak részlegesen kapcsolódó kérdésre is, így különösen az adott társaság megalapítására okot adó célrendszerre, hiszen ha egy társaság már nem tudja betölteni a rendeltetését, az állam által számára megfogalmazott alapvető célrendszernek nem tud megfelelni, akkor megkérdőjeleződhet az adott társaság létjogosultsága is. Azt is kiemeltük, hogy egy szervezet megfelelőségének vizsgálatakor valójában arra keressük a választ, hogy annak működési mechanizmusai alárendelhetők-e a szervezetre vonatkozó valamennyi elöírásnak, a vele szemben megfogalmazott célkitűzéseknek és elvárásoknak. Megfogalmaztuk az állami vállalatok tekintetében érvényesítendő megfelelőség szűkebb és tágabb fogalmát: szűkebb értelemben a megfelelőség egy gazdasági társaságra vonatkozó jogi szabályozók - ide értve a tulajdonos döntéseit is - betartását és betartatását jelenti. Tágabb értelemben azonban sokkal többet jelent: az adott gazdasági társasággal szemben már az alapításkor megfogalmazott célkitűzéseknek, a tulajdonosi, esetenként kormányzati szinten megfogalmazott előírásoknak, a szakpolitikai (ágazati) szintű szabályozóknak, szabványoknak, a közszolgáltatást igénybe vevők által támasztott elvárásoknak, a szervezet által magával szemben lefektetett rövid, közép-, és hosszú távú stratégiai céljainak, a vezetőkkel és a munkavállalókkal szemben megfogalmazott vállalati értékeknek való megfelelést is jelenti. Azt is láttuk, hogy a hazai jogrendszerben már megkezdődött egy folyamat a jogi megfelelőség szabályozását illetően a hitelintézeti, illetve a biztosítási szférában.

Arra is rávilágítottunk, hogy az állami vállalatok tekintetében érvényesítendő számos előírás ellenőrzése a különböző ellenőrzési hatáskörrel rendelkező szervezetek együttmüködésén alapul. Nem hagyható figyelmen kívül azonban a társaságok vezető tisztségviselőinek a megfelelőség biztosításában betöltött szerepe. Ehhez normatív szintủ támpontokat az Áht., a Bkr. és az Intr. ${ }^{19}$ már most is biztosítanak. Ez a kör kiegészül az Állami Számvevőszék hiánypótló kutatásaival ${ }^{20}$ és felméréseivel, amelyek évről évre iránymutatásul szolgálnak az állami tulajdonú társaságok szervezeti integritásának és megfelelőségének biztosításához (Németh, Martus, Vargha et al., 2019), (lásd

\section{3. táblázat).}

Kétségtelen, hogy az állami tulajdonú gazdasági társaságok megfelelőségének és szervezeti integritásának növelése, hatékonyságának fokozása számos eszköz útján lehetséges (Németh E., Martus B., Vargha B., 2018). Ezek között vannak olyanok, amelyek a szervezeten belül, az állami vállalat vezetőinek és munkavállalóinak az elkötelezettségét és a megfelelőségi kultúra kialakításának az igényét feltételezik. Létezik az eszközöknek olyan csoportja is, amelyek kívülről, a tulajdonosi joggyakorló és/ vagy a szakpolitikai irányítást vagy felügyeletet gyakorló által kerülhet megfogalmazásra. Természetesen ezek szervezeti integrálása is a tár- 


\section{AZ INTEGRITÁS KIÉPÍTETTSÉGÉNEK TERÖLETEI (2016-2018)}

\begin{tabular}{|c|c|c|}
\hline $\begin{array}{c}\text { Az integritáskontrollok } \\
\text { kiépítettségének terïletei } \\
\text { 2016-ban }\end{array}$ & $\begin{array}{c}\text { Az integritáskontrollok } \\
\text { kiépítettségének terïletei } \\
\text { 2017-ben }\end{array}$ & $\begin{array}{c}\text { Az integritáskontrollok } \\
\text { kiépítettségének területei } \\
\text { 2018-ban }\end{array}$ \\
\hline $\begin{array}{l}\text { - Vagyongazdálkodás, közpénzek } \\
\text { - kezelése, } \\
\text { - Vállalatirányítás, felügyelet, } \\
\text { nyúijtása, } \\
\text { - Szervezeti struktúra, } \\
\text { - Beszerzések, közbeszerzések, } \\
\text { - Jogi környezet, } \\
\text { - Belső szabályozottság, } \\
\text { - Humánerőforrás-gazdálkodás, } \\
\text { - Belsố kontrollok, } \\
\text { kockázatkezelés, } \\
\text { - Speciális korrupcióellenes } \\
\text { rendszerek, eljárások. }\end{array}$ & $\begin{array}{l}\text { - Felelős irányitás (tulajdonosi vagyon } \\
\text { rendelkezésre bocsátása, jogi környezet, } \\
\text { felügyelőbizottság szerepe, beszámolás } \\
\text { tulajdonos irányába, tulajdonos döntési } \\
\text { hatásköre, társaságirányitás, szervezeti } \\
\text { struktúra kialakítása, vezetői információs } \\
\text { rendszer); } \\
\text { - Közfeladat-ellátás, külső kapcsolatok } \\
\text { (közfeladat ellátása, közszolgáltatás } \\
\text { nyújtása, dijmegállapítás, külső } \\
\text { szervezeteknek nyúitott támogatás, tôllük } \\
\text { támogatás elfogadása, szerződéses } \\
\text { partnerek kockázatai, kiszervezés, } \\
\text { közzététel, nyilvánosság); } \\
\text { - Gazdálkodás (vagyongazdálkodás, } \\
\text { uniós támogatás, partnerszerződések, } \\
\text { vállalatcsoport, gazdálkodási hatékonyság); } \\
\text { - Megfelelőség, ellenőrzések (belső } \\
\text { szabályozottság, közbeszerzés, } \\
\text { ajánlattétel, könyvvizsgálat, külső és belső } \\
\text { ellenőrzések); } \\
\text { - Szervezeti kultúra, etikus magatartás } \\
\text { (integritási kultúra a belső szabályokban, } \\
\text { magáncéllú juttatások, munkatársak } \\
\text { kiválasztása, összeférhetetlenség, } \\
\text { teljesítményértékelés, etikai eljárás, } \\
\text { médiamegjelenés). }\end{array}$ & $\begin{array}{l}\text { A } 2017 \text {-es elemzésben nevesített } \\
\text { területeken túl: } \\
\text { - Külső kapcsolatok: külső } \\
\text { támogatásokban való részesedés, } \\
\text { illetve támogatás nyúitása, } \\
\text { a támogatások elszámolása, } \\
\text { ügyfelek elégedettségének } \\
\text { mérése, közérdekű adatok } \\
\text { közzététele. } \\
\text { - Külső és belső ellenőrzések: } \\
\text { könyvvizsgálat, külső szervek } \\
\text { által végzett ellenőrzések, } \\
\text { belső ellenőrzések színvonala, } \\
\text { hasznosulása, kockázatelemzés } \\
\text { és kockázatkezelés. } \\
\text { - Szervezeti kultúra: } \\
\text { emberierő́forrás-gazdálkodás, } \\
\text { összeférhetetlenség } \\
\text { szabályozása, illetve felmérése } \\
\text { a munkatársak kiválasztása } \\
\text { során, javadalmazási rendszer, } \\
\text { teljesítményértékelés, etikai } \\
\text { eljárások. }\end{array}$ \\
\hline
\end{tabular}

Forrás: saját összeállitás az Állami Számvevőszék 2016-2018. évi integritási felmérései alapján

saság vezetőjének a felelőssége. Végezetül lehetséges ezeket a kérdéseket normatív eszközökkel is befolyásolni, hogy csak a legfontosabbakat említsük (Pulay, Kovács, 2019). Az ellenőrzés hatékonyságának fokozásához ezeket az ellenőrzési mechanizmusokat összehangoltan kell igénybe venni, és biztosítani kell az ellenőrzést lefolytatók közötti együttműködést.
Ahogyan említettük, elöremutató lenne egy önálló jogszabály elfogadása az állami tulajdonú társaságok belső kontrollrendszerére vonatkozóan. Ilyen jogszabály (kormányrendelet) elfogadására már most is lehetőséget ad az Áht. már említett 69/A. \$-a.

A már említett hitelintézeti és biztosítási normák szabályai mellett a Bkr. és az Intr. sza- 
bályait figyelembe véve célszerü lenne szabályozni az alábbiakat:

- a belső kontrollrendszer kialakításáért, működtetéséért és fejlesztéséért az állami tulajdonú gazdasági társaság vezető tisztségviselője felelős,

- a belső kontrollrendszer kialakítása során figyelembe kell venni a szervezet egyedi sajátosságait,

- célszerü integrálni a Bkr. kontrollkörnyezet kialakítására vonatkozó, a költségvetési szervek tekintetében már jól bevált szabályait,

- a hitelintézeti és a biztosítási jog területén törvényi szinten is szabályozott rendelkezésekhez hasonlóan a jogszabályi megfelelőség biztosításának a követelményét normatív szinten is célszerü meghatározni, azonban ezen túlmenően a megfelelöség tágabb értelemben vett fogalmából kiindulva elvárásként kell megfogalmazni az állami tulajdonú gazdasági társaságok értékeinek, céljainak, a kapcsolódó közfeladat megvalósításának a megfelelőségi elvárásait, az etikus működés biztosításához szükséges intézkedések meghatározásának szükségességét is,

- a megfelelőségi bejelentési/panaszkezelési rendszer működtetése a privátszféra gazdasági társaságainál egy jól bevált gyakorlat.
Néhol teljesen független személy, vagy testület vizsgálja az ilyen jellegü bejelentéseket. Ennek intézményesítése az állami tulajdonú gazdasági társaságok esetében is javasolt,

- a megfelelőséget és a szervezeti integritást érintő kérdéseket a tulajdonosi joggyakorló egységes iránymutatása alapján célszerü az egyedi társasági jellegzetességekre figyelemmel kimunkálni a szervezeti szabályozók szintjén,

- megfontolandó a belső ellenőrzésre vonatkozó rendelkezések állami tulajdonú társaságokra vonatkozó nevesítése is az említett jogi szabályozó szintjén. Ezzel kapcsolatban érdemes megerősíteni a belső ellenőr és az egyéb ellenőrzési funkciókat ellátó testületek, szervezetek kapcsolatát és együttmüködését (például a felügyelőbizottsággal, a könyvvizsgálóval, a compliance szervezettel),

- az Állami Számvevőszék integritás jelentéseiben megfogalmazottak és a nemzetközi megfelelőségi standardok vállalati szabályozásba való integrálása a tulajdonosi joggyakorló ellenőrzési kompetenciájába tartozó kérdésként kezelendő.

Reméljük tanulmányunkkal hozzájárultunk a megfelelőség kérdéskörének állami, vállalati szempontú megvilágításához és a szabályozási környezet kialakításának sarokköveihez.

JEGYZETEK

1 Forrás: www.mnv.hu (2019. 06. 12.)

2 Online: http://www.mnvzrt.hu/felso_menu/ tarsasagi_portfolio/elektronikus_aukcios_rendszer_ portfolio/ear_portfolio.html (2019.06.03.)

3 Ld. ehhez az MNV Zrt. árverési felületét. Online: https://e-arveres.mnv.hu/index-meghirdetesekuzletresz.html?.actionId=action.common.Select
AuctionTypeAction \&item = partnerMainPage $\&$ FRAME_SKIP_DEJAVU $=1$ \&auction Type $=3$ (2019.06. 03.)

4 Értve ezalatt a megbízásba vagy vagyonkezelésbe adott társasági részesedéseket.

5 Lásd a vállalkozások statisztikai célú nyilvántartása közös keretének létrehozásáról és a 2186/93/EGK 
tanácsi rendelet hatályon kívül helyezéséről szóló 77/2008/EK Rendelet (9) preambulumbekezdését.

${ }^{6}$ OECD Guidelines on Corporate Governance of State-Owned Enterprises. Online: http:// www.oecd.org/corporate/guidelines-corporategovernance-SOEs.htm 3. (2019. 05. 25.)

7 2013-ban az Európai Gazdasági és Szociális Bizottság „Az EU versenyképességének kihasználatlan gazdasági lehetőségei - az állami vállalatok reformja” címü feltáró véleményében kifejtette, hogy az államnak gondoskodnia kell a tényleges állami ellenőrzésről és a valódi állami szabályozásról, amelynek az állami vállalatok irányítás összes érintettjének, valamint a vállalati dolgozók képviselőinek részvételén kell alapulnia.

8 A Vtv. 29. \$ (3) bekezdése alapján gazdálkodó szervezet alapítására, illetve abban részesedés szerzésére és a tulajdonosi (tagsági, részvényesi, alapítói) jogok gyakorlására - ha törvény vagy a Vtv. 3. $\$(2 a)$ bekezdése szerinti miniszteri rendelet eltérően nem rendelkezik - az állam nevében az MNV Zrt. jogosult. Emellett gazdálkodó szervezet alapítása során történő eljárásra, valamint társasági részesedés állam nevében történő megszerzésére az MNV Zrt. más személynek, szervezetnek meghatalmazást adhat.

${ }^{9}$ Ld. az Áht. 61. \$-át.

${ }^{10}$ Ld. a Vtv. 2. \$ (4) bekezdését.

${ }^{11}$ Ld. a Vtv. 17. $\$(1)$ bekezdésének $d$ ) pontját.

${ }^{12}$ https://allamhaztartas.kormany.hu/belso-ellenorzesiszakmai-anyagok (2019. 05. 21.).

${ }^{13}$ Összhangban a tagállamok költségvetési keretrendszerére vonatkozó követelményekről szóló 2011/85/EU Irányelvvel.

${ }^{14}$ A Közlemény II. része a 2017-ben megszűnt, il- letve kisorolt olyan, kormányzati szektorba sorolt egyéb szervezeteket tartalmazza, amelyek tekintetében azok jogutódját, ennek hiányában pedig a számviteli szabályok szerinti beszámolójának elkészítésére kötelezett a 2017. évre nézve még utólagos adatszolgáltatásra kötelezett.

${ }^{15}$ A Közlemény $B$ ) pontja pedig a Helyi önkormányzati alszektorba sorolt szervezetekről.

${ }^{16}$ Emellett alapítványok, közalapítványok, hitelintézeti szervezetek, alapok, hatóságok találhatók még ebben a részben.

${ }^{17}$ Ld. a Bkr. 1. \$-át.

${ }^{18}$ Módszertani útmutató az államigazgatási szervek korrupciómegelőzési helyzetének felméréséhez, korrupcióellenes kontrolljai kiépítéséhez és érvényesítésük ellenőrzéséhez. https://korrupciomege lozes.kormany.hu/download/3/70/41000/M\% C3\%B3dszertani\%20\%C3\%BAtmutat\%3\% B3.pdf (2019. 07. 13.)

${ }^{19} \mathrm{Az}$ államigazgatási szervek integritásirányítási rendszeréről és az érdekérvényesítők fogadásának rendjéről szóló 50/2013. (II. 25.) Korm. rendelet.

${ }^{20}$ Állami Számvevőszék: Elemzés a többségi állami tulajdonú gazdasági társaságok körében végzett integritásfelmérés eredményeiről 2016. Elérhető: https://www.asz.hu/storage/files/files/ Publikaciok/Elemzesek_tanulmanyok/2016/ gt_integritas_tanul many.pdf?ctid=976 (2019. 04 . 25.); Állami Számvevőszék: Tanulmány a köztulajdonú gazdasági társaságok 2017. évi integritás helyzetéről. Elérhető: https://www.asz.hu/storage/files/ files/Publikaciok/Elemzesek_tanulmanyok/2018/ integritas_elemzes_20180425.pdf?ctid=1237 (2019. 04. 25.); Állami Számvevőszék: Tanulmány a köztulajdonú gazdasági társaságok 2018. évi integritás helyzetéről. Elérhető: https://asz. hu/storage/files/files/elemzesek/2019/20190320_ kgt_int.pdf (2019. 04. 25.) 


\section{IRODALOM}

Boros, A. (2017). OECD Guidelines on Corporate Governance of State-Owned; Enterprises from Hungarian State-Owned Enterprises'Point of View; Pro Publico Bono, 1. különszám, 6-25. oldal

Doмокоs, L. (2011). Hitelesség és rugalmasság. Pénzügyi Szemle, (3.), 285. oldal, 285-296. oldal

Doмокоs, L. (2016). Az Állami Számvevőszék jogosítványainak kiteljesedése az új közpénzügyi szabályozás keretében. Pénzügyi Szemle, (3.), 299-319. oldal

Domokos L., Pulay Gy., Pető K., Pongrácz É. (2015). Az Állami Számvevőszék szerepe az államháztartás stabilitásának megteremtésében. Pénzügyi Szemle, (4.), 427-443. oldal

Domokos L., Várpalotai V., Jakovác K., MakKai M., Németh E., Horváth M. (2016). Szempontok az állammenedzsment megújításához. Fókuszban az állami és önkormányzati tulajdonú gazdasági társaságok irányítása. Pénzügyi Szemle, (2.), 185-204. oldal

Gyüre Lajosné (2012). Belső kontrollok kialakítása és működtetése az önkormányzati vagyongazdálkodás kockázatainak csökkentésére. Pénzügyi Szemle, (2.), 183-193. oldal

James, S., Alley, C. (2009). Tax Compliance, Self-Assessment and Tax Administration. Journal of Finance and Management in Public Services, 2019. 06. 05., pp. 28-42, Online: https://ore.exeter.ac.uk/ repository/bitstream/handle/10036/47458/james2. pdf?seq

Cramer J. A., Roy A., Burrell A., Carol J. F., Mahesh J. F., Daniel A. O., Peter K. Wong (2008). Medication Compliance and Persistence: Terminology and Definitions. Value in Health, (1.), pp. 44-47, https://doi.org/10.1111/j.1524-4733.2007.00213
KIs N. (2015). Antikorrupció és közszolgálati integritás: Magyarország az európai uniós törekvések tükrében. In.: Dargay E., Juhász L. (szerk.): Antikorrupció és integritás, NKE, Budapest, 17-18. oldal

KovÁcs Á. (2007). Az ellenörzés rendszere és módszerei. Perfekt Kiadó, Budapest, 317. oldal

KovÁcs Á. (2016). A Költségvetési Tanács a magyar Alaptörvényben. Vázlat az intézményfejlődésről és az európai uniós gyakorlatról. Pénzügyi Szemle, (3.), 320-337. oldal

KovÁcs Á. (2014). Költségvetési tanácsok KeletKözép-Európa országaiban. Pénzügyi Szemle, (3.), 345-363. oldal

KovÁcs T., SzóKa K. (2016). Belső kontrollfunkciók a pénzügyi intézményekben - szabályozás és annak felépítése Magyarországon. Gazdaság és Társadalom, (3.), 69-82. oldal, https://doi.org/10.21637/gt.2016.3.05.

Lentner Cs. (2015a). A vállalkozás folytatása számviteli alapelvének érvényesülése közüzemi szolgáltatóknál és költségvetési rend szerint gazdálkodóknál magyar, európai jogi és eszmetörténeti vonatkozásokkal. In: Lentner Csaba (szerk.). Adózási pénzügytan és államháztartási gazdálkodás: Közpénzügyek és Allamháztartástan II. NKTK, 763-783. oldal

Lentner Cs. (2015b). Az új magyar állampénzügyi rendszer - történeti, intézményi és tudományos összefüggésekben. Pénzügyi Szemle, (60.) 4., 458 472. oldal

Lentner, Cs. (2018). Excerpts on new hungarian state finances from legal, economic and international aspects In: Pravni Vjesnik. Casopis za pravne i drustvene znanosti Pravnog fakulteta. Sveucilista Josipa Jurja Strossmayera u Osijeku, (34) p. 2, 9., https://doi.org/10.25234/pv/5996 
Lentner Cs. (2019). A magyar állampénzügyek fejlödéstörténete a dualizmus korától napjainkig. L'Harmattan, Budapest, 197. 224. és 250-258. oldal

Németh E., Martus B. Sz., Vargha B. T., Teski N. (2019). A közszféra integritásának elemzése új módszertan alapján 2018. Budapest, Állami Számvevőszék

Németh E., Martus B., Vargha B. (2018). Közszolgáltatások integritáskockázatai és kontrolljai. Integrity Risks and Controls of Public Services. Pénzügyi Szemle, (2), 161-181. oldal

Németh E., Martus B., Szabó B. S. (2016): Integritás felmérés: Közintézmények, 2016 - Kutatási jelentés, http://real.mtak.hu/43294/1/Integritas_ jelentes_2016_print_2.0_u.pdf (2019.07. 13.)

Polanyai, K. (2001). The Great Transformation. The Political and Economic Origons of Our Time. Beacon Press, p. 317
ZÉMAN Z. (2017). A pénzügyi controlling kockázatcsökkentő szerepe önkormányzati szervezeteknél. A jövedelmezőségi és a likviditási vetület modellezése. Pénzügyi Szemle, (3.), 294-309. oldal

Pulay Gy., Kovács K. I. (2019). A Közszolgáltató társaságok integritásának erősségei és gyenge pontjai. Észak-magyarországi Stratégiai Füzetek. GazdaságRégió-Társadalom, Miskolci Egyetem Gazdaságtudományi Kar, (1.), 35, http://www.strategiaifuzetek. hu/files/148/Strategiai\%20fuzetek_2019_1.pdf (2019. 05. 27.).

Pulay Gy., Jenei Z-né (2016). RÉS-elemzés: Módszer a szervezeti integritás kiépítésének és müködése ellenőrzésének elősegítésére. Új Magyar Közigazgatás, (4.), 3. oldal

A megfelelőségi ellenőrzés alapelvei. https://asz. hu/storage/files/files/Ellenorzes_szakmai_szabalyok/ Ellenorzes_szakmai_szabalyok_rendszere/10_a_ megfelelosegi_ellenorzes_alapelvei.pdf (2019. 07. 13.) 3. oldal 